\title{
Impact of endocrine disrupters on ovarian function and embryonic development
}

\author{
F. Gandolfi ${ }^{\mathrm{a}, *}$, P. Pocar ${ }^{\mathrm{b}}$, T.A.L. Brevini ${ }^{\mathrm{a}}$, B. Fischer ${ }^{\mathrm{b}}$ \\ a Instituto di Anatomia degli Animali Domestici, Via Celoria, 1020133 Milano, Italy \\ ${ }^{\mathrm{b}}$ Institute of Anatomy, Martin Luther University, Halle-Saale D, Milano, Italy
}

\section{Introduction}

During the past 50 years, a variety of synthetic chemicals have been released in the environment as a consequence of efforts expended to increase agricultural productivity or as a result of modern manufacturing processes and their by-products. We have recently become aware that several of these substances, known as "endocrine disrupters" (ED) [1], are able to modulate and/or disrupt hormone homeostasis through different pathways [2]. These chemicals include herbicides, pesticides, fungicides, plasticizers, polystyrenes, polychlorinated biphenyls (PCBs), polychlorinated dibenzodioxins and alkylphenolic compounds [1,3]. Although many of these chemicals have a weak hormonal activity if compared with endogenous hormones, their lipophilic nature and long half-life allow them to accumulate and persist in fatty tissues of the body, thus increasing their concentration and bioavailability $[4,5]$.

Although ED have adverse impacts on different hormone-dependent functions, e.g., immune and thyroid dysfunction [6,7], the research was mainly focused on development and reproduction. The interference of ED with normal development of male and female reproductive organs as well as with reproductive functions in adulthood has been well documented, in both wildlife and experimental animals (for review [1,8]). Published data indicate that chemical exposures may cause alterations in reproductive behavior and contribute to sub-fecundity, infertility, pregnancy loss, growth retardation, intrauterine fetal demise, birth defect, and ovarian failure (for review $[9,10]$ ). To date, the physiological consequences for farm animals of ED ingestion is largely unknown. However, the levels of exposure to these chemicals in domestic ruminants are such than when studying fertility problems in these species the impact of

\footnotetext{
* Corresponding author. Tel.: +3902-5031-7990; fax: +3902-5031-7980.

E-mail address: gandolfi@imiucca.csi.unimi.it (F. Gandolfi).
} 
exposure to ED via food and drinking water cannot be neglected. Recently, indirect evidence of negative effects is provided by a study that demonstrate an association between exposure of dairy cattle to drinking water contaminated with sewage overflows and reduced reproductive performance [11]. Monitoring the negative impact of ED on reproduction is important for the animal breeding industry, which is vulnerable to the inadvertent disposal of potentially dangerous chemicals. In particular, it is important to study the effect of ED on the female reproductive physiology since farm animal reproduction is based on the use of a limited number of males, usually under a strict management, and on the use of a large number of females exposed to a wide range of different environmental conditions.

The aim of this presentation is to review the most recent data available on the negative effects of ED on farm animal reproduction with particular emphasis on cattle for its important economic role in agriculture. Special attention will be paid to those chemicals that have the potential to impair ovarian function, since ovary is critical to normal reproduction and its lesions can have long-term effect on reproductive fitness. We will attempts to summarize, from a cellular and molecular standpoint, the actual knowledge on ED that exhibit ovarian toxicity by destruction of oocytes, examining in particular the maturation process.

\section{Environmental chemicals affecting ovarian function}

Female reproductive function can be compromised by exposure to toxic chemicals [12] at a variety of sites, including the hypothalamus, pituitary, ovary or reproductive tract $[13,14]$. Disruption of any of these sites can ultimately manifest as a disruption of ovarian function, resulting in infertility.

The ovary performs two important roles, delivery of the female gametes (oocytes) and production of ovarian hormones-e.g., estrogen, progesterone, and inhibin $[15,16]$. How reproductive toxicants can affect ovarian function is generally not well understood but their effects can be due to one of several possible mechanisms. Indirect effects on ovarian function might result from altered pituitary output of gonadotrophins (FSH and $\mathrm{LH}$ ) due to disruption of neuroendocrine feedback by estrogen and progesterone. Alternatively, reproductive toxicants can have direct ovarian effects on steroid hormone production, affecting oocyte maturation and early maintenance of pregnancy. By a different route, ED can affect ovarian function through the destruction of oocytes. Oocyte destruction can result from a toxic chemical directly impairing the oocyte viability. Conversely, because oocytes at all stages of development are surrounded by granulosa cells, these mechanisms might also be indirect, involving alterations within the granulosa cells, which compromise their ability to maintain oocyte viability [17]. Extensive destruction of oocytes damages ovarian follicles that, in turn, destroys steroid hormone production and can result in ovarian failure. Therefore, oocyte destruction ultimately can disrupt the endocrine balance causing a reduction in estrogen and progesterone and an elevation in FSH and LH.

For chemicals that destroy the oocytes, the stage of development at which the follicle is destroyed determines the impact that the exposure to the chemical will have on reproduction. Compounds that extensively destroyed oocytes contained in primordial and primary follicles may have a delayed effect on reproduction until such a time that recruitment for the number 
of growing and antral follicles can no longer be supported [18,19]. Conversely, chemicals that selectively damage large growing or antral follicles generally, only temporarily interrupt reproductive function because this follicles can be replaced by recruitment from the greater pool of primordial follicles. Thus, these chemicals produce a readily reversible form of infertility that is manifest relatively soon after exposure [20,21].

Another factor related to the effect of exposure to a reproductive toxicant is the level of exposure required to produce an ovarian damage. It is only under rare circumstances that individuals are exposed acutely to toxic levels of ovotoxic chemicals, and the effects can usually be detected and evaluated. However, the effects of chronic exposure to levels of toxicants are more difficult to determine. Because of their insidious nature, this type of exposure can cause "silent" damage and are of the greatest concern.

\section{Polychlorinated biphenyls: a useful model}

\subsection{Background}

Polychlorinated biphenyls (PCBs) are one of the various classes of environmental contaminants that have been observed to affect oocyte maturation. PCBs are members of the group of halogenated aromatic hydrocarbons (HAHs) and consist of 209 isomers and congeners with different numbers and positions of chlorine atoms substituted on the biphenyl moiety (Fig. 1). PCBs were synthesized for approximately 60 years from the early 1920s until they were banned in many countries during the late 1970s. Their uses varied from closed-system applications in capacitors and transformers to open-system applications in the manufacture of adhesives, textiles and printing. Obviously, such a plethora of uses has facilitated their ubiquity in the environment. It is estimated that $10^{8} \mathrm{~kg}$ of PCBs still reside in the biosphere [22]. Moreover, high concentrations of PCBs are known to be present in sewage sludge from industrial, agricultural and domestic origin that is spread on arable land and pasture as fertilizer [23] and are found in water $[24,25]$. Farm animals ingest these substances with food and drinking water and it is likely that the rates of ingestion will increase in the future as growing amounts of sewage sludge are recycled onto agricultural land [23].

PCBs are small molecules $(\mathrm{Mw}=188-498)$ with a low solubility in water, but high solubility in organic solvents, oils and fat [26]. As a results of this lipophilic nature and the stability and resistance to degradation, PCBs congeners accumulate in the animal and human body and can be found at all levels of the food chain [27,28]. Measurable concentrations of these compounds

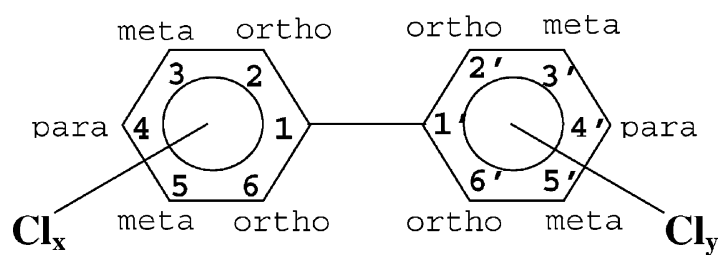

Fig. 1. The structure of the PCB molecule. 
were found not only in the adipose tissues but also in fluids of the female genital tract [29]. It was Trapp [30] who first demonstrated the presence of these chlorinated hydrocarbons in the follicular fluid of women (in a mean of $553 \mathrm{ng} / \mathrm{g}$ ) and highlighted the potential threat to reproductive health posed by these contaminants. Since then several study reported the presence of PCBs in human follicular fluid in concentrations up to $1600 \mathrm{ng} / \mathrm{g}$ [31-33]. Furthermore, PCBs have been detected in human ovarian tissue [34], human embryos and fetuses [35]. Different toxic responses, including reproductive toxicity, have been observed in laboratory and wild animals after exposure to PCB mixtures (for review [36,37]). It appears that PCBs have a systemic effect on reproduction with multiple targets. However, to date which biological functions are affected is not yet delineated. Rodents exposed to PCBs have experienced a reduction in the germ cell number, a decrease in the reproductive organ weights, a reduced number of implantation sites, embryotoxicity and reduced litter size [38-40]. Reproductive disorders have also been observed in non-human primates. Alterations of the menstrual cycle and increased incidence of abortions and embryo resorption were observed in monkeys exposed to Aroclor-1248 [41]. Some of these studies suggest direct and indirect effects of PCBs on ovarian function. For example, in rats exposed to the commercial mixture Aroclor-1242, a reduction in the number of follicles was observed [42]. In rhesus monkeys, administration of PCBs altered menstrual cycle, induced amenorrhea [41] and inhibited ovulation in 50\% of treated animals [43]. To date, data on the direct effects of these compounds on oocytes are still scarce.

\subsection{PCBs and oocyte maturation}

The ovotoxic potential of PCBs has been studied in different species both using in vivo and in vitro models. Bioassays of final oocyte maturation were conducted with ED that displayed estrogenic/antiestrogenic activity in fishes. Particularly, a mixture of 20 PCBs were tested in Zebrafish orally exposed to in three different dose levels $(0.008,0.08$ and $0.4 \mu \mathrm{g}$ of each congeners per gram of freeze-dried chironomids). Generally the PCBs accumulated in the body and inhibited oocyte maturation in a concentration-dependent manner [44].

Very few studies have been conducted on possible toxic effects of PCBs on mammalian oocytes and embryos. Preliminary observations indicated that human embryos derived from follicles with elevated pollutant concentrations had low cleavage rate as observed after IVF [30].

Kholkute et al. $[45,46]$ tested the effects of technical mixtures, such as Aroclor-1254 and -1268 , on the in vitro maturation and fertilization of mouse oocytes. Their results indicated that the addition of PCB mixtures in the maturation medium, at concentrations ranging from 0.01 to $10 \mu \mathrm{g} / \mathrm{mL}$, affect the fertilizing capability of the oocytes. Exposure to A-1254 at a concentration of $10 \mu \mathrm{g} / \mathrm{mL}$ failed to reveal any significant effect on the viability rate of the oocytes, although morphology and structural changes have not been evaluated [45]. Furthermore, Greenfeld et al. [47] observed that A-1254 at the same concentrations did not affect the fertilization competence of exposed cumulus-free mouse oocytes, suggesting a possible role of cumulus cells in PCB-induced toxicity.

At present, only two main studies were conducted to evaluate the effects of PCBs on bovine oocytes. It is not common to use bovine oocytes as a model in toxicological research; however, 
a vast background knowledge is available on the oocyte biology in this species. The relevance of these studies resides in two major aspects: (1) a better understanding of the mechanisms involved in oocyte and embryo developmental competence and of the molecular mode by which exposure to environmental chemicals may compromise ruminant fertility is of prime importance for agricultural economy. In fact, female farm animals, like cows, are chronically exposed over long periods of time and chronic as well as accidental contamination of cattle feed by PCBs is possible [48]; (2) despite potential species differences can never be ruled out, there are many similarities between human and bovine reproduction, and cattle can be chosen as good animal model for human reproductive risk assessment. In both species, final maturation of the oocyte takes place in the ovaries, triggered by the LH-surge, just prior to ovulation, and, normally, only one oocyte ovulates. Fertilization takes place in the ampullary tract of the oviduct, and the conceptus enters the uterus after 3-4 days in humans and approximately 1 day later in cows. The formation of the blastocyst occurs after 4-5 days in the human and after 7-8 days in the cow.

Krogenaes et al. [49] demonstrated adverse effects of PCB 153 (non-coplanar) and PCB 126 (coplanar) addition to the maturation medium on bovine oocytes. Particularly, PCB 153 demonstrated no direct effects on maturation but resulted in a reduced percentage of oocytes that are completed the first cell cycles. In contrast, PCB 126 showed negative effects on maturation at the highest concentrations employed and also adversely affected subsequent embryo development at the lowest levels of exposure. The concentration range used for this study was comparable with the levels observed in serum of non-exposed women $(0.001$ and $0.4 \mathrm{ng} / \mathrm{g}$ for PCB 126 and 153, respectively [50]). These results are significant since the levels of persistent organic pollutants in follicular fluid have been reported to be similar to those in the serum [51]. Moreover, PCB 153, as a major and very stable PCB congener, has been shown to correlate directly to the total amounts of PCBs [31].

More recently, studies conducted in our laboratory investigated the adverse effects of exposure of bovine oocytes during the maturation process to Aroclor-1254, a technical mixture of PCBs whose composition is considered as environmentally relevant [52]. In fact, several lines of evidence indicate that mixtures of PCBs are more toxic than individual congeners [53]. This is of ecological significance since mixtures, not individual congeners, were used industrially and have accumulated in the environment [54-56]. In this study, A-1254 at concentrations as low as $0.01 \mu \mathrm{g} / \mathrm{mL}$, significantly decreased the percentage of oocyte reaching the metaphase II. This probably resulted from a block or a delay of the maturation process, since a significant increase in the percentage of oocytes arrested at the metaphase I was observed. Furthermore, PCB exposure during maturation significantly decreased the fertilizing ability of the oocyte while increasing polyspermy. The negative effect of Aroclor-1254 addition in the maturation medium did not appear to be limited to maturation and fertilization, but included embryonic development, since a significant decrease in the proportion of cleaved embryos that reached the blastocyst stage, was observed. Consistently with the results of Krogenaes et al. [49] fertilization and embryonic development were affected by a PCB concentration $(0.001 \mu \mathrm{g} / \mathrm{mL})$ lower than that required for inducing the reduction of maturation rate, indicating that for the assessment of the risk posed by these compounds, it is necessary to complete an analysis of the different phases of development [52]. 


\subsection{PCBs and cytoplasmic maturation}

There are a number of ways by which PCBs could affect oocyte in vitro maturation. All the studies conducted so far failed to detect degenerated oocytes or a reduction in oocytes viability suggesting that PCB did not exert a direct toxic effect on the oocyte $[45,49,52]$. However, detailed morphological examination following PCB treatment was not conducted and minor changes cannot be ruled out. Maturation stages were always determined by the evaluation of nuclear morphology [57]. However, this evaluation did not allow the assessment of cytoplasmic maturation, a process through which immature oocytes acquire the competence to be fertilized and to sustain embryo development. It is characterized by ultrastructural and spatial rearrangements of the ooplasm as well as by chemical changes of the molecules stored therein $[58,59]$. For this reason, in our recent studies, a set of experiments was designed to examine the effects of the exposure of bovine oocytes to a dose of Aroclor-1254 known to be detrimental to nuclear maturation and subsequent embryo development, on two important aspects of the cytoplasmic maturation of bovine oocytes: modulation of maternal mRNA polyadenylation [60] and cortical granules (CGs) migration and exocytosis [61].

It is generally accepted that mRNA and protein molecules synthesized during oocyte growth and maturation contribute to early development prior to zygote genome activation [62]. The storage of mRNA takes place during oocyte growth and the extent of poly(A) tail at the $3^{\prime}$ end of the transcripts has emerged as an important regulatory element for determining their stability [63] and represents a key regulatory step for early embryonic development [60,64]. Our results demonstrate that A-1254 induces changes in the polyadenylation pattern of 5 out of 10 genes examined indicating a perturbing effect exerted by this contaminant on the translational regulation of these transcripts. However, PCBs action on polyadenylation seems to be different from that of other factors affecting oocyte competence. For instance, when reduction of developmental competence is induced by removing gonadotrophins from the maturation medium, only those transcripts that would normally undergo deadenylation during the maturation process display an alteration of the poly(A) tail. Transcripts that either become adenylated or do not change during maturation are not affected by the absence of gonadotrophins [60]. On the contrary, oocyte exposure to A-1254 during IVM induces polyadenylation changes in a more varied way: as described for gonadotrophins, PCBs induced a more pronounced deadenylation of some of the genes that would deadenylate in control conditions (i.e., GT-Ty1, Cx43, Plako); however, at the same time, a longer poly(A) tail was observed at the $3^{\prime}$ end of $\mathrm{Cx} 32$, a gene that normally readenylates during maturation. Finally, another pattern has been observed for HSP70, where instead of undergoing a deadenylation process as in control conditions, this messenger RNA showed an extension of the poly(A) tail at the end of IVM [65].

A common attribute of cytoplasmic maturation is the migration and the redistribution of organelles, including cortical granules (CGs), in temporal coordination with the nuclear stages. In A-1254 exposed oocytes, the majority of the gametes exhibited a delay in migration and dispersal of the cortical granules, which points to an impaired cytoplasmic maturation. In addition, the analysis of fertilized oocytes showed a significantly higher percentage of zygotes, positively correlated with the rate of oocytes that presented multiple fertilization after IVF, 
that failed to release the CGs after sperm penetration [65]. A similar study conducted on cumulus-free mouse oocytes, showed that A-1254 exposure during maturation does not induce the spontaneous cortical granule exocytosis [47]. It is then possible that PCBs could block the molecular pathways that triggers CGs exocytosis, and consequentially cause polyploidy, as the slow block to polyspermy would not be created.

\section{Arylhydrocarbon receptor}

\subsection{Background}

Among the halogenated aromatic hydrocarbons, various congeners showed differential abilities to bind to a cytosolic receptor, the arylhydrocarbon receptor (AhR, also known as dioxin receptor since 2,3,7,8-tetrachlorodibenzo- $p$-dioxin (TCDD) is its most potent agonist). Non-ortho substituted PCB congeners have a coplanar structure similar to TCDD and elicit similar toxicity. PCBs with single ortho-chlorine slightly favor the non-coplanarity and behave as weak AhR agonists. Finally, PCB congeners with two or more ortho-chlorines highly favor the non-coplanar conformation. Thus, this group of congeners does not bind to the AhR and exhibit different toxicity [66].

AhR is a member of the basic helix-loop-helix Per-Arnt-Sim (bHLH-PAS) protein superfamily and its mechanism of action is shown in Fig. 2. Unligated AhR is located in the cytoplasm, associated with two molecules of Heat Shock Protein 90 (HSP90) and with the AhR interaction factor (AIF) [67]. These proteins are thought to keep the AhR in a state responsive to ligand binding. Upon ligand binding, the HSP90 molecules are displaced and the AhR enters the nucleus, where it complexes with its nuclear partner ARNT (Ah Receptor Nuclear Translocator; another member of the bHLH protein family [68]). The newly formed heterodimer represents the functional DNA-binding complex (AhRC). Transcriptional control involves AhRC binding to specific DNA enhancer sequences known as xenobiotic responsive element (XRE) [69] and induces transcription of specific target genes [70]. Generally products of these genes fall into one or two broad categories: drug-metabolizing enzymes and growth-regulatory proteins. The most extensively studied AhR-target gene is cytochrome P450 1A1 (CYP 1A1), a protein involved in the metabolism of a large number of xenobiotics [71]. Other genes for phase I and II enzymes, known to be under AhR control are cytochrome p450 1A2 (CYP 1A2) and cytochrome p450 1B1 (CYP 1B1) [72], NAD(P)H-menadione oxidoreductase (MNO1), glutathione S-transferase (GST), and a tumor specific aldehyde dehydrogenase (ADH4) [73]. Changes in these metabolic enzymes do not appear to mediate directly the effects of the ligand; however, they play their role, in some cases, activating "pretoxicants" to their ultimate cytotoxic form and, in other cases, detoxifying potentially dangerous xenobiotics. Several genes that encode growth-regulatory proteins appear also to be responsive to AhR agonists. This group includes genes for the epidermal growth factor receptor, the estrogen receptor, interleukin $1 \beta$ and transforming growth factors-alpha and -beta1. There has been no direct demonstration that aberrations in expression of any of these genes is responsible for the toxic effects of TCDD-like compounds, but recent work suggests that some of them can play a critical role in the toxic action of TCDD [74]. 


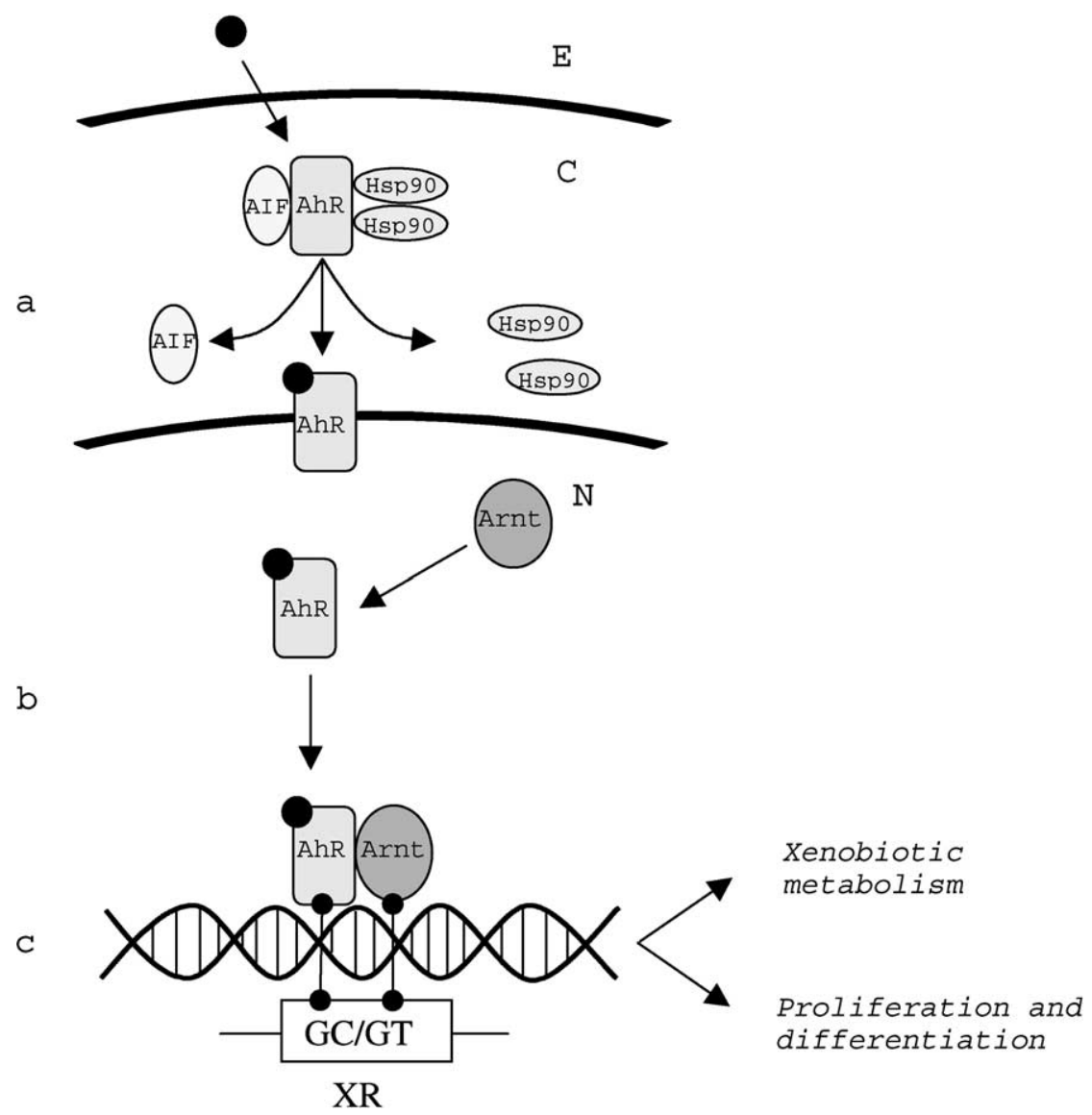

Fig. 2. Outline of the arylhydrocarbon receptor (AhR) function as a ligand-activated transcription factor. (a) AhR resides in the cytoplasm (C) complexed with the AhR interaction Factor (AIF) and two molecules of Heat Shock Protein 90 (HSP90). The ligand diffuses through the membrane from the extra cellular side (E) and binds the AhR. (b) Ligand-bound AhR enters the nucleus $(\mathrm{N})$ and dimerizes with ARNT. (c) The AhR-ARNT complex binds the XRE and activates target gene transcription. Genes that are under control of the AhR belongs to two major functional groups: (1) Induction of several drug-metabolizing enzymes can alter the biotransformation activity for endogenous and exogenous substances, potentially leading to both beneficial and detrimental effects; (2) Aberrant regulation of genes that regulate cell proliferation and differentiation may underline the toxic manifestations of many aromatic hydrocarbons.

\subsection{Is AhR involved in PCB mixture toxicity?}

Several lines of evidence give a strong indication of an involvement of the AhR in the toxicity elicited by PCB mixtures in different tissues and cell types [75]. In order to understand how PCBs interfere with bovine oocyte developmental competence, we, therefore, decided to study the expression of AhR and its nuclear partner ARNT in bovine cumulus-oocyte complexes and its possible activation by A-1254 exposure during the maturation period.

Bovine cumulus-oocyte complexes expressed AhR transcript and protein. The receptor protein was detected exclusively in the cytoplasm of both oocyte and somatic cells. ARNT 
transcript and protein were coexpressed with $\mathrm{AhR}$ in the cumulus cells. Interestingly, in contrast to AhR, the oocyte did not express ARNT and the expression appeared restricted to the granulosa cells, showing a strong nuclear localization [76].

After exposure to oocyte-toxic concentrations of A-1254 during the maturation period, we were unable to demonstrate any nuclear translocation of the receptor in the granulosa cells nor to observe the induction of expression of four different target genes (CYP 1A1 and 1A2, ADH4 and GST) [76]. These findings are consistent with previous observation in mice: in vivo exposure to different well known activators of the AhR (the polycyclic aromatic hydrocarbons, benzo(a)pyrene, 3-methylcholantrene and 7,12-dimetylbenz(a)anthracene) induced oocyte destruction in the ovary of both Ah-responsive and Ah-non-responsive strains. This study demonstrated that also in this species the toxic effect of these compounds was not mediated by the ovarian AhR activity [77].

These results indicate a highly specific pattern of expression of the AhR signaling components in the bovine cumulus-oocyte complexes, suggesting a possible functional role of these molecules during oocyte growth and maturation. This role will need further clarification and characterization. Furthermore, these findings support the hypothesis that Aroclor-1254 toxicity, at the concentrations that affect oocyte maturation and developmental competence, is more likely to be related with cellular pathways other then the AhR signaling pathways.

\section{Summary and future directions}

In summary, published data clearly indicate that PCB (singly or in combination) disrupt mammalian oocyte maturation even at very low concentrations, acting through different cellular and molecular mechanisms. Nevertheless, it is still unclear which specific cellular pathway(s) these compounds activate, therefore the search for specific mechanisms of PCB ovotoxicity at the molecular level should be the focus of future research in this field.

In more general terms, future research should systematically identify environmental chemicals that can disrupt the normal development and function of the reproductive system. To date, in fact, only 40 or so environmental pollutants have been identified as endocrine disrupters $[1,8]$ and most of them have been identified by casualty rather then as a result of a logical and exhaustive screening processes. This can be achieved only if appropriate biomarkers for risk assessment in mammals are identified, and used together with the development of appropriate and simplified in vitro markers of reproductive toxicity that enable the widespread screening of all potentially toxic compounds.

\section{References}

[1] Colborn T, vom Saal FS, Soto AM. Developmental effects of endocrine-disrupting chemicals in wildlife and humans. Environ Health Perspect 1993;101:378-84.

[2] Neubert D. Vulnerability of the endocrine system to xenobiotic influence. Regul Toxicol Pharmacol 1997;26: 9-29.

[3] Peterson RE, Theobald HM, Kimmel GL. Developmental and reproductive toxicity of dioxins and related compounds: cross-species comparisons. Crit Rev Toxicol 1993;23:283-335. 
[4] Holliger C, Gaspard S, Glod G, Heijman C, Schumacher W, Schwarzenbach RP, Vazquez F. Contaminated environments in the subsurface and bioremediation: organic contaminants. FEMS Microbiol Rev 1997;20: $517-23$

[5] Hooper K, McDonald TA. The PBDEs: an emerging environmental challenge and another reason for breast-milk monitoring programs. Environ Health Perspect 2000;108:387-92.

[6] Smialowicz RJ, Andrews JE, Riddle MM, Rogers RR, Luebke RW, Copeland CB. Evaluation of the immunotoxicity of low level PCB exposure in the rat. Toxicology 1989;56:197-211.

[7] Vos JG, van Loveren H. Markers for immunotoxic effects in rodents and man. Toxicol Lett 1995;82/83:385-94.

[8] Toppari J, Larsen JC, Christiansen P, Giwercman A, Grandjean P, Guillette Jr LJ, Jegou B, Jensen TK, Jouannet P, Keiding N, Leffers H, McLachlan JA, Meyer O, Muller J, Rajpert-De Meyts E, Scheike T, Sharpe R, Sumpter J, Skakkebaek NE. Male reproductive health and environmental xenoestrogens. Environ Health Perspect 1996;104(Suppl 4):741-803.

[9] Bhatt RV. Environmental influence on reproductive health. Int J Gynaecol Obstet 2000;70:69-75.

[10] Sharara FI, Seifer DB, Flaws JA. Environmental toxicants and female reproduction. Fertil Steril 1998;70: 613-22.

[11] Meijer GAL, Wagenaar JA, Bree dJ, Spoelstra SF. Riooloverstorten: risico's voor de gezondheid van melkvee. In: ID-Lelystad, 1997, report nr: 97028.

[12] Mattison DR. Clinical manifestation of ovarian toxicity. In: Dixon R, editor. Reproductive toxicology, vol. 109. New York: Raven Press, 1985. p. 109-30.

[13] Mattison DR. Morphology of oocyte and follicle destruction by polycyclic aromatic hydrocarbons in mice. Toxicol Appl Pharmacol 1980;53:249-59.

[14] Thomas JA. Toxic responses of the reproductive system. In: Amdur M, Doull J, Klassen C, editors. Toxicology. New York: McGraw-Hill, 1993. p. 484-520.

[15] Richards JS. Maturation of ovarian follicles: actions and interactions of pituitary and ovarian hormones on follicular cell differentiation. Physiol Rev 1980;60:51-89.

[16] Hirshfield AN. Development of follicles in the mammalian ovary. Int Rev Cytol 1991;124:43-101.

[17] Buccione R, Schroeder AC, Eppig JJ. Interactions between somatic cells and germ cells throughout mammalian oogenesis. Biol Reprod 1990;43:543-7.

[18] Generoso WM, Stout SK, Huff SW. Effects of alkylating chemicals on reproductive capacity of adult female mice. Mutat Res 1971;13:172-84.

[19] Hooser SB, Douds DP, DeMerell DG, Hoyer PB, Sipes IG. Long-term ovarian and gonadotropin changes in mice exposed to 4-vinylcyclohexene. Reprod Toxicol 1994;8:315-23.

[20] Jarrell JF, Bodo L, YoungLai EV, Barr RD, O'Connell GJ. The short-term reproductive toxicity of cyclophosphamide in the female rat. Reprod Toxicol 1991;5:481-5.

[21] Davis BJ, Maronpot RR, Heindel JJ. Di-(2-ethylhexyl) phthalate suppresses estradiol and ovulation in cycling rats. Toxicol Appl Pharmacol 1994;128:216-23.

[22] Boyle AW, Silvin CJ, Hassett JP, Nakas JP, Tanenbaum SW. Bacterial PCB biodegradation. Biodegradation 1992;3:2-3.

[23] Wild SR, Jones KC. Organic chemicals entering agricultural soils in sewage sludges: screening for their potential to transfer to crop plants and livestock. Sci Total Environ 1992;119:85-119.

[24] Abbassy MS, Ibrahim HZ, el-Amayem MM. Occurrence of pesticides and polychlorinated biphenyls in water of the Nile river at the estuaries of Rosetta and Damiatta branches, north of Delta, Egypt. J Environ Sci Health B 1999;34:255-67.

[25] Fingler S, Drevenkar V, Tkalcevic B, Smit Z. Levels of polychlorinated biphenyls, organochlorine pesticides, and chlorophenols in the Kupa River water and in drinking waters from different areas in Croatia. Bull Environ Contam Toxicol 1992;49:805-12.

[26] Ballschmiter K, Rappe C, Buser HR. Chemical properties, analytical methods and environmental levels of PCBs, PCTs, PCNs and PBBs. In: Kibrough RD, Jensen AA, editors, Halogenated biphenyls, terphenyls, naphtalenes, dibezodioxins and related products. Amsterdam: Elsevier Science, 1989 [chapter 2]. p.47-102.

[27] Jones KC. Determination of polychlorinated biphenyls in human foodstuffs and tissues: suggestions for a selective congener analytical approach. Sci Total Environ 1988;68:141-59. 
[28] McFarland VA, Clarke JU. Environmental occurrence, abundance, and potential toxicity of polychlorinated biphenyl congeners: considerations for a congener-specific analysis. Environ Health Perspect 1989;81:225-39.

[29] Lindenau A, Fischer B, Seiler P, Beier HM. Effects of persistent chlorinated hydrocarbons on reproductive tissues in female rabbits. Hum Reprod 1994;9:772-80.

[30] Trapp M, Baukloh V, Bohnet HG, Heeschen W. Pollutants in human follicular fluid. Fertil Steril 1984;42: $146-8$.

[31] Pauwels A, Covaci A, Delbeke L, Punjabi U, Schepens PJ. The relation between levels of selected PCB congeners in human serum and follicular fluid. Chemosphere 1999;39:2433-41.

[32] Jarrell JF, Villeneuve D, Franklin C, Bartlett S, Wrixon W, Kohut J, Zouves CG. Contamination of human ovarian follicular fluid and serum by chlorinated organic compounds in three Canadian cities. CMAJ 1993; 148:1321-7.

[33] Baukloh V, Bohnet HG, Trapp M, Heeschen W, Feichtinger W, Kemeter P. Biocides in human follicular fluid. Ann N Y Acad Sci 1985;442:240-50.

[34] Mes J, Marchand L, Davies DJ. Organochlorine residues in adipose tissue of Canadians. Bull Environ Contam Toxicol 1990;45:681-8.

[35] Nishimura M, Shiota K, Tanimura T, Mizutani T, Matsumoto M, Veda M. Levels of polychlorinated biphenyls and organochlorine insecticides in human embryos and fetuses. Paediatrician 1977;6:45-7.

[36] Safe SH. Polychlorinated biphenyls (PCBs): environmental impact, biochemical and toxic responses, and implications for risk assessment. Crit Rev Toxicol 1994;24:87-149.

[37] Ahlborg UG, Brouwer A, Fingerhut MA, Jacobson JL, Jacobson SW, Kennedy SW, Kettrup AA, Koeman JH, Poiger H, Rappe C, Safe SH, Seegal RF, Tuomisto J, Van Den Berg M. Impact of polychlorinated dibenzo-p-dioxins, dibenzofurans, and biphenyls on human and environmental health, with special emphasis on application of the toxic equivalency factor concept. Eur J Pharmacol 1992;228:179-99.

[38] d'Argy R, Dencker L, Klasson-Wehler E, Bergman A, Darnerud PO, Brandt I. 3,3'4,4'-Tetrachlorobiphenyl in pregnant mice: embryotoxicity, teratogenicity, and toxic effects on the cultured embryonic thymus. Pharmacol Toxicol 1987;61:53-7.

[39] Linzey AV. Effects of chronic polychlorinated biphenyls exposure on growth and reproduction of second generation white-footed mice (Peromyscus leucopus). Arch Environ Contam Toxicol 1988;17:39-45.

[40] Ronnback C, de Rooij DG. Effects of 3,3',4,4'-tetrachlorobiphenyl on foetal germ cells in two mouse strains after repeated treatment of the dams during and after pregnancy. Pharmacol Toxicol 1994;74:287-93.

[41] Barsotti DA, Marlar RJ, Allen JR. Reproductive dysfunction in rhesus monkeys exposed to low levels of polychlorinated biphenyls (Aroclor 1248). Food Cosmet Toxicol 1976;14:99-103.

[42] Jonsson HT, Keil JE, Gaddy RG, Loadholt CB, Hennigar GR, Walker EM. Prolonged ingestion of commercial DDT and PCB; effects on progesterone levels and reproduction in the mature female rat. Arch Environ Contam Toxicol 1975;3:479-90.

[43] Muller WF, Hobson W, Fuller GB, Knauf W, Coulston F, Korte F. Endocrine effects of chlorinated hydrocarbons in rhesus monkeys. Ecotoxicol Environ Saf 1978;2:161-72.

[44] Orn S, Andersson PL, Forlin L, Tysklind M, Norrgren L. The impact on reproduction of an orally administered mixture of selected PCBs in zebrafish (Danio rerio). Arch Environ Contam Toxicol 1998;35:52-7.

[45] Kholkute SD, Rodriguez J, Dukelow WR. Reproductive toxicity of Aroclor-1254: effects on oocyte, spermatozoa, in vitro fertilization, and embryo development in the mouse. Reprod Toxicol 1994;8:487-93.

[46] Kholkute SD, Dukelow WR. Effects of polychlorinated biphenyl (PCB) mixtures on in vitro fertilization in the mouse. Bull Environ Contam Toxicol 1997;59:531-6.

[47] Greenfeld CR, Xiongqing W, Dukelow WR. Aroclor 1254 does not affect the IVF of cumulus-free mouse oocytes. Bull Environ Contam Toxicol 1998;60:766-72.

[48] Malisch R. Increase of the PCDD/F-contamination of milk, butter and meat samples by use of contaminated citrus pulp. Chemosphere 2000;40:1041-53.

[49] Krogenaes AK, Nafstad I, Skare JU, Farstad W, Hafne AL. In vitro reproductive toxicity of polychlorinated biphenyl congeners 153 and 126. Reprod Toxicol 1998;12:575-80.

[50] Johansen HR, Becher G, Polder A, Skaare JU. Congener-specific determination of polychlorinated biphenyls and organochlorine pesticides in human milk from Norwegian mothers living in Oslo. J Toxicol Environ Health 1994;42:157-71. 
[51] Kimbrough RD. Polychlorinated biphenyls (PCBs) and human health: an update. Crit Rev Toxicol 1995;25:133-63.

[52] Pocar P, Perazzoli F, Luciano AM, Gandolfi F. In vitro reproductive toxicity of polychlorinated biphenyls: effects on oocyte maturation and developmental competence in cattle. Mol Reprod Dev 2001;58:411-6.

[53] Stack AS, Altman-Hamamdzic S, Morris PJ, London SD, London L. Polychlorinated biphenyl mixtures (Aroclors) inhibit LPS-induced murine splenocyte proliferation in vitro. Toxicology 1999;139:137-54.

[54] Fromberg A, Cleemann M, Carlsen L. Review on persistent organic pollutants in the environment of Greenland and Faroe Islands. Chemosphere 1999;38:3075-93.

[55] Sather PJ, Ikonomou MG, Addison RF, He T, Ross PS, Fowler B. Similarity of an Aroclor-based and a full congener-based method in determining total PCBs and a modeling approach to estimate Aroclor speciation from congener-specific PCB data. Environ Sci Technol 2001;35:4874-80.

[56] Alcock RE, Behnisch PA, Jones KC, Hagenmaier H. Dioxin-like PCBs in the environment-human exposure and the significance of sources. Chemosphere 1998;37:1457-72.

[57] Xu KP, Greve T, Smith S, Hyttel P. Chronological changes of bovine follicular oocyte maturation in vitro. Acta Vet Scand 1986;27:505-19.

[58] Hyttel P, Fair T, Callesen H, Greve T. Oocyte growth, capacitation and final maturation in cattle. Theriogenology 1997;47:23-32.

[59] Brevini Gandolfi TAL, Gandolfi F. The maternal legacy to the embryo: cytoplasmic components and their effects on early development. Theriogenology 2001;55:1255-76.

[60] Brevini-Gandolfi TA, Favetta LA, Mauri L, Luciano AM, Cillo F, Gandolfi F. Changes in poly(A) tail length of maternal transcripts during in vitro maturation of bovine oocytes and their relation with developmental competence. Mol Reprod Dev 1999;52:427-33.

[61] Damiani P, Fissore RA, Cibelli JB, Long CR, Balise JJ, Robl JM, Duby RT. Evaluation of developmental competence, nuclear and ooplasmic maturation of calf oocytes. Mol Reprod Dev 1996;45:521-34.

[62] Telford NA, Watson AJ, Schultz GA. Transition from maternal to embryonic control in early mammalian development: a comparison of several species. Mol Reprod Dev 1990;26:90-100.

[63] Richter JD. Dynamics of poly(A) addition and removal during development. In: Hershey J, Mathews M, Sonenberg N, editors. Translational control. New York: Cold Spring Harbor Laboratory Press, 1996. p. 481-503.

[64] Vassalli JD, Stutz A. Translational control. Awakening dormant mRNAs. Curr Biol 1995;5:476-9.

[65] Pocar P, Brevini TAL, Perazzoli F, Cillo F, Modina S, Gandolfi F. Cellular and molecular mechanisms mediating the effects of polychlorinated biphenyls on oocyte developmental competence in cattle. Mol Reprod Dev 60:535-41.

[66] Fischer LJ, Seegal RF, Ganey PE, Pessah IN, Kodavanti PR. Symposium overview: toxicity of non-coplanar PCBs. Toxicol Sci 1998;41:49-61.

[67] Ma Q, Whitlock JP. A novel cytoplasmic protein that interacts with the Ah receptor, contains tetratricopeptide repeat motifs, and augments the transcriptional response to 2,3,7,8-tetrachlorodibenzo-p-dioxin. J Biol Chem 1997;272:8878-84.

[68] Hoffman EC, Reyes H, Chu FF, Sander F, Conley LH, Brooks BA, Hankinson O. Cloning of a factor required for activity of the Ah (dioxin) receptor. Science 1991;252:954-8.

[69] Denison MS, Fisher JM, Whitlock JP. The DNA recognition site for the dioxin-Ah receptor complex. Nucleotide sequence and functional analysis. J Biol Chem 1988;263:17221-4.

[70] Rowlands JC, Gustafsson JA. Aryl hydrocarbon receptor-mediated signal transduction. Crit Rev Toxicol 1997;27:109-34.

[71] Delescluse C, Lemaire G, de Sousa G, Rahmani R. Is CYP1A1 induction always related to AHR signaling pathway? Toxicology 2000;153:73-82.

[72] Okey AB, Riddick DS, Harper PA. Molecular biology of the aromatic hydrocarbon (dioxin) receptor. Trends Pharmacol Sci 1994;15:226-32.

[73] Nebert DW, Puga A, Vasiliou V. Role of the Ah receptor and the dioxin-inducible Ah gene battery in toxicity, cancer, and signal transduction. Ann N Y Acad Sci 1993;685:624-40.

[74] Yang JH, Vogel C, Abel J. A malignant transformation of human cells by 2,3,7,8-tetrachlorodibenzo-p-dioxin exhibits altered expressions of growth regulatory factors. Carcinogenesis 1999;20:13-8. 
[75] Whitlock JP. Genetic and molecular aspects of 2,3,7,8-tetrachlorodibenzo- $p$-dioxin action. Annu Rev Pharmacol Toxicol 1990;30:251-77.

[76] Fischer B, Hasan A, Kietz S, Pocar P. Ah receptor expression and signal transduction in bovine and rabbit reproductive tissues and embryos. In: Proceedings of the British Society of Animal Science 2001, abstract no. 64.

[77] Mattison DR, Nightingale MS. Oocyte destruction by polycyclic aromatic hydrocarbons is not linked to the inducibility of ovarian aryl hydrocarbon (benzo(a)pyrene) hydroxylase activity in (DBA/2N X C57BL/6N) F1 X DBA/2N backcross mice. Pediatr Pharmacol 1982;2:11-21. 